\title{
Development of Craft and Entrepreneurship Module for Green Economy
}

\author{
Dwi Arifianti $^{1}$, Wiedy Murtini ${ }^{1}$ and Tri Murwaningsih ${ }^{1}$ \\ ${ }^{1}$ Sebelas Maret University Surakarta, Indonesia \\ Corresponding e-mail: dwiarifianti3007@gmail.com
}

\begin{abstract}
This study aims to: (1) knowing the needs analysis in the development of module based craft and entrepreneurial of green economy, (2) Examine the appropriateness of modules craft and entrepreneurial based on green economy, (3) Analyze the effectiveness of the module craft and entrepreneurial on green economy, to improve learning outcomes in entrepreneurship students.

Research and development of craft and entrepreneurship module uses 8 of 10 step development of Borg and Gall which has been modified by Sugiyono. Analysis of the data used for the development of descriptive analysis, probability analysis module is based on the score criteria by using t-test.

Based on results of the descriptive analysis of the validator module craft and entrepreneurial based on green economy obtained results are: (1) expert learning materials at 86.20 with very good criteria; (2) a media expert at 89.82 with very good criteria; (3) a linguist at 100 with very good criteria; (4) expert practitioners amounted to 93,89 with very good criteria. Based on the results of analysis the validator it can be concluded that the module craft and entrepreneurial based green economy worthy be used to improve students learning outcomes.

The result of posttest test in the control class has an increase from the pretreatment of 69,86 up to 70,92 and the experimental class experimental test has increased from the average value of 69,53 which experienced an increase in posttest i.e. the mean value to 83,71 . Learning outcomes show that the craft module and entrepreneurship are able to improve student learning outcomes on the subject of craft and entrepreneurship. This is evidenced by the increase in student learning outcomes in the experimental class higher than the control class.
\end{abstract}

\section{Keywords: Development, modules, green economy, learning outcomes}

\section{INTRODUCTION}

The rapid development of science requires the world of education in Indonesia to move forward and develop. Global competition demands Indonesia's human resources to be more competent. Competent human resources must be supported by a high level of education. Thus, efforts are needed to improve the quality of education. Education is an absolute tool for realizing a society capable of mastering and exploiting the increasingly evolving science and technology.

Based on data from the Central Bureau of Statistics the number of open unemployment in February 2016 amounted to 7.02 million or 5.5\%. However, the number of unemployed people decreased when compared to February 2015, which reached 7.45 million people $(5.81 \%)$. Based on the level of education, the percentage of 
under-graders dropped from $3.61 \%$ to $3.44 \%$, the percentage of unemployed junioreducated residents also declined, from $7.14 \%$ to $5.76 \%$, the percentage High schooleducated residents declined from $8.17 \%$ to $6.95 \%$, the University's graduate unemployment rate increased from 5.34\% to $6.22 \%$. Therefore, efforts are needed to improve the quality of education in Indonesia, especially for Vocational High School (SMK) in order to be able to choose a career, competence and develop themselves in the business scope in accordance with the purpose of the school.

In the 2013 curriculum entrepreneurship subjects in vocational schools have been combined into a craft and entrepreneurship, where in entrepreneurship learners should be able to create products for their work to be a business opportunity. Jepara is one of the districts in Central Java which is a large industrial area, which produces various handicrafts from wood, cloth, monel and others. The rapid growth of industrial handicrafts in Jepara has resulted in large waste of production. Lack of utilization of industrial waste in Jepara caused by bad impact on the environment, therefore in planting environmentally friendly education on the students early on is expected to be a solution to reduce environmental pollution. As the younger generation of the nation, students are invited to preserve the environment by utilizing waste of production into various kinds of crafts as business opportunities. Early environmental education must be absorbed by children, so that children have a wider environmental insight into adults and are expected to be more concerned about the environment in the area.

With the existence of some of these problems make the challenges facing education increasingly heavy and demands that education to life-oriented (Life Skill) so that later after graduation learners already have the skills and talents. One way, which can be done is to develop learning modules that are integrated with the green economy of production. Green economy production is an effort to recycle or utilize waste from industry to become valuable craft and be able to create business opportunity. Instructional materials in the form of modules are designed to assist teachers in providing learning experiences that involve mental and physical processes through the interaction of learners, learners with teachers, the environment, and other learning resources in order to achieve the desired competencies [1].

Module is an effective media learning to improve student learning outcomes. This is supported by previous researches [2,3]. Based on several studies that have been done, no one has developed a green economy-based module or developed a module that incorporates elements of green economy to enhance student's activity that leads to improved learning outcomes. According to the Directorate General of Quality Assurance of Education and Education Personnel (2008: 3) module is a printed material that is designed to be studied independently by the participants of the learning. The module is also called the media for self-study because it has been equipped with instructions for self-study.

The facts found in SMK N 3 Jepara from the observations on the learning and entrepreneurial learning on January 12, 2017 and January 17, 2017 found some problems. Which are, Information from teachers of the craft and entrepreneurship modules used in the learning process of entrepreneurship and it is incomplete and not yet based on green economy which can be interpreted as a low-carbon economy (not producing emissions and environmental pollution), saving natural resources and social justice [4]. Instructional materials craft and entrepreneurship also has not included three learning domains (Bloom's Taxonomy) which includes cognitive, affective and psychomotor. The learning process of craft and entrepreneurship applied in SMK N 3 
Jepara using lecture method, nothing that students are less active in the learning process. Teachers are less utilizing the facilities and infrastructure of the available entrepreneurial laboratories. The media learning for the subjects of craft and entrepreneurship that have not supported the process of learner activity on learning activities. Another problem found is the attitude of students in following lazy learning, it is caused by the learning materials and entrepreneurial craft less attractive for students, so that this attitude impact on the material and student learning outcomes to learn the craft and entrepreneurship.

Study of craft and entrepreneurship has the right character to disturb with the mastery of knowledge, attitudes and skills that must be mastered by the students. Characteristics of the module of entrepreneurship are based on green economy is on the learning objectives there are activities and steps to make craft from textile waste. Implementation of the learning objectives in each subject there are drawings / charts of the steps to perform the practice of making a craft of industrial waste accompanied by information and pictures.

\section{Definition of Learning}

Understanding of learning expressed by the Syah (2008: 94) which states that "learning is the most vital in the business of education, so without learning actually there is no education" [5]. As a learning process almost always gets a wide place in various disciplines related to educational efforts such as educational psychology. Because of the importance of the meaning of learning, the greatest part of the research effort and educational psychology experiments is directed at achieving a broader understanding of the process of human change.

According to Heinich, Molenda, Russell, \& Smaldino (2002: 6) states that "learning is the development of new knowledge, skills, or attitudes as an individual interacts with information and the environment [6]. The learning environment includes the physical facilities, the psychological atmosphere, instructional methods, media, and technology ". Learning is the development of new knowledge, skills, or attitudes as an individual who interacts with information and the environment. Learning environment includes physical facilities, psychological atmosphere, learning methods, media, and technology). "Learning is modifying or reinforcing behavior through experience" [7].

Schunk (2012: 3) defines "Learning is an enduring change in behavior, or in the capacity to behave in a given fashion, which results from practice or other forms of experience" [8]. This means learning is a change of behavior that is relatively settled resulting from past experiences or from learning that aims. While Nokelainen (2006: 179) "Learning is a largely unobservable and uncontrollable process that happens all the time" [9]. Learning is a largely unobserved and uncontrolled process that occurs over time.

\section{Teaching Materials}

Understanding the teaching materials delivered by the University of Willongong NSW 2522 (1992: 33) "they are the information, module equipment and text for instructors that are required for planning and review upon training implementation. Text and training equipment included in the teaching materials. This means teaching materials are information, tools and text that teachers need to plan and review the 
implementation of learning. The text and learning tools are included in the teaching materials.

Bundsgaard \& Hansan (2011: 32) states, "learning materials as artifacts, e.g. Textbooks, blackboards, computer ". It means teaching materials are artifacts, such as textbooks, whiteboards, and computers. Opinions from Belawati (2003: 12) teaching materials are, "Materials or learning materials are arranged systematically, used for teachers and students in the learning process" [12]

According to Hashemi \& Borheni (2012: 2656) "The textbook is an almost universal element of teaching. So the textbook is an important means of satisfying the range of needs that emerge from the classroom and its wider contexts " [2012]. This means that textbooks are a common element used in teaching, so textbooks are an important means to satisfy the various needs that arise from the class and the broad context. Hackbarth (1996: 80) points out that: "Textbooks introduce students to a structured body of knowledge and acquaint them with the terms and principles needed to acquire it. Study question and suggested activities often found in accompanying work books enable students to test and increase their knowledge. Tables of contents, indexes, and bibliographies allow to pursue topic on their own" [14].

This means that textbooks introduce students to the content of the structure of knowledge and introduce them to the terms and principles necessary to acquire them, study questions and suggest an activity often found in the work that accompanies the book enables students to test and improve their knowledge.

\section{Learning Module}

The module is, "Learning tools or tools that contain material, methods, limitations, and ways of evaluating systematically and attractively designed to achieve the expected competence according to their level of complexity" [15]. According to Winkel (2009: 472) "the learning module is the smallest unit of learning, which is learned by the students themselves individually or taught by students to themselves self-instructional". Existing modules can be used by learners with independent learning so that learners can learn in accordance with the ability they have so that all the competencies that must be mastered by learners can be fulfilled [16].

According to Cruces (1993: 2) "A module is defined as a set of learning opportunities systematically organized around a well-defined topic that contains the elements of instruction-specific objectives, teaching activities and evaluation using criterion-reference measures". Meaning a module is defined as a learning unit systematically organized around topics containing elements of purpose of specific instruction, teaching and evaluation activities using reference-criteria steps [17].

Dewitt, Siraj \& Alias (2014: 89) states, "Presently, text modules have been used for language instruction where messages can be pushed as textual learning objects". Meaning currently, text modules have been used for teaching where messages can be encouraged as objects of textual learning

Perinpasingam, Arumugam, Subramaniam, at all (2014: 31) "The module served as a pedagogical tool that seems to be a feasible solution to the inquisitive learning of science and confidence of school". This means that the Module as a pedagogical tool that becomes a viable solution to enhance learning as well as science and beliefs of students [19] 


\section{Green Economy}

Djajadaningrat, Hendriani \& Famiola (2014: 1) states, 'The green economy, which is the science of promoting prosperity, social justice and advocating for reducing the scarcity of natural resources and the risk of environmental impacts'. The definition of green economy according to the offer letter of green economy training number 0317 / p.01 / 01/2003 issued by the Ministry of National Development Planning is, "New economic order that uses less energy from natural resources" [20]. So the application of green economy is to apply new economic concepts that oriented by improving economic aspects while still paying attention to environmental sustainability in development activities. UNEP (2011: 11) defines green economy as: "One that results in improved human well-being and social equity, while significantly reducing environmental risks and ecological scarcities. It is low carbon, resource efficient and socially inclusive [4]. In a green economy, growth in income and employment should be driven by public and private investment that reduce carbon emissions and pollution, enhance energy and resource efficiency, and prevent the loss of biodiversity and ecosystem services"

UNEP (2011: 11) states that the understanding of green economy is broader in scope than Low-Carbon Economy (LCE) or Low-Fossil-Fuel Economy (LFFE), ie economic activity that gives minimal output to Green Houses Gas (GHG) emissions released. The new economic model is based on ecological economics knowledge that discusses the economic dependence of humans on natural ecosystems and the effects of human economic activity on climate change and global warming [4].

World Bank (2012: 2) states, "Green growth is growth that is efficient in its use of natural resources, clean in that it minimizes pollution and environmental impacts, and resilient in that it accounts for the natural hazards and the role of environmental management and Natural capital in preventing physical disasters ". This means that green growth is an efficient growth in the use of natural resources, clean in it that minimizes pollution and environmental impacts, and resilient in terms of reducing natural disasters and the role of environmental management and natural capital to prevent physical disaster.

According to OECD (2011: 9), "Green growth means fostering economic growth and development, while ensuring that natural assets continue to provide the resources and environmental services on which our well-being relies." This means green growth means encouraging economic growth and development, while ensuring the natural wealth that continues to provide environmental resources and services for our wellbeing. In line with OECD, Janicke (2012: 21) states "Link green growth and green economies to the promising changes in the ecoindustry sector, shifting from downstream environmental protection technology to resource-saving technologies, based on innovation and competitive markets". This means green growth and green economy linking to promising changes in the ecoindustry sector, shifting from downstream environmental protection technologies to resource-saving technologies, based on innovation and competitive markets [22].

Tomuka in (Sari, Wijaya, \& Wachid, 2015: 766) raises the characteristic of green economy as follows: 1 . a low carbon economy green economy spurs to minimize the use of carbon dioxide gas produced by industry with fossil fuels [23]. This gas is a greenhouse gas that produces global warming. Green economy is what does not produce carbon. 2. Resource Efficient, i.e. the efficiency of existing natural resources. 
Examples of natural resources (SDA) include water, forests, winds, coal, and so forth. Green economy is an efficient use of natural resources. 3. Social inclusive, economics in favor of most society.

\section{Study of Craft and Entrepreneurship}

The subjects of craft and entrepreneurship are subjects that develop knowledge and train life skills based on art and technology based on economics. The learning of craft and entrepreneurial begins by training the creativity in pouring ideas and ideas into a productive person and can improve the skills that lead to the appreciation of renewable technology. Agronomic and applicative results in using the environment by taking into account ecosystem, management, economic and local cultural wisdom. Entrepreneurship is becoming very popular in Indonesia as a solution to reduce the number of unemployed. According to Bygrave (Alma, 2011: 21), "Entrepreneur is the person who achieve an opportunity and creates an organization to pursue it". Based on that definition an entrepreneur is a person who sees opportunities and then creates an organization to take advantage of these opportunities.

According to Alma (2011: 26), "Entrepreneurship the process of creating something different with value by devoting then necessary time and effort, assuming the accompanying financial, psychic, and social risks, and receiving the resulting rewards of monetary and personal satisfaction and independence" [24]. This means entrepreneurship is the process of creating something else by using time and activities accompanied by capital and risks and receive compensation and satisfaction and personal freedom. Kao in Lo Choi Tung (2011: 33) "entrepreneurship is the process of doing something new or different with the goal of creating wealth for individuals and adding value to society.

\section{Learning Outcomes}

Kettunen, Mertanen, \& Penttila (2013: 337) argue about learning outcomes, namely "Learning outcomes are statements which are used to describe the results of the learning period, the knowledge and know-how at the end of a certain period Of learning "(The learning outcomes are statements used to describe specifically what a student should expect in terms of understanding, knowledge and knowing how at the end of a particular learning period) [25].

Nokelainen (2006: 179) "Learning is a largely unobservable and uncontrollable process that happens all the time". Learning is a largely unobserved and uncontrolled outcome that happens all the time. Learning outcomes are the product of the learning process that includes the cognitive, affective, and psychomotor aspects, it is as revealed by Lezzio that, "Learning outcomes is a product of the learning process which covers three aspects: cognitive, affective, and psychomotor outcome" (Asgari \& Borzooei, 2013: 134). This means that learning outcomes are a product of the learning process that includes three aspects: cognitive, affective and psychomotor. Watson defines "A learning outcome as a result that a result of a learning experience" (Maher, 2013: 46). Meaning is the result of learning as something that students can do now that they cannot do before, changes to students as a result of the learning experience [27]. 


\section{RESEARCH METHODS}

The selected research development model is a research and development model developed by Borg and Gall (2007: 589), where research development is a research oriented to developing and validating the products used in education [28]. Validation of the craft and entrepreneurship module is done by material experts, linguists, media experts and practitioners who will then be tested on students on a small scale. This model is chosen, because the revision step is always put after the test action is done. The test is done gradually in accordance with the components to be tested specifically so that the revision is more directed in accordance with the components tested.

Research development is done in SMK Negeri 3 Jepara. This research is to know the effectiveness, feasibility of developed module. The effectiveness and feasibility of the module are known through trials. Module testing conducted small / limited group and field trials in SMK Negeri 3 Jepara. Small group trials were conducted for small classes with a total of 10 students. Results from small / limited group trials are used as inputs for module improvements that will be used in field trials. The data collection instrument uses questionnaires, observation sheets and tests.

\section{RESEARCH RESULT AND DISCUSSION}

The result of validation of expert module of craft and entrepreneurship based on green economy that developed later on through to know the result. Processed data is data relating to product feasibility obtained based on validation from various expert experts, media experts, linguists and practitioners. The data were obtained through questionnaires, notes, and suggestions. Suggestions and feedback can be called as follows.

Description of the data from the module validation by the material experts got a total score of 86.20 with very good category. Aspects in the value, among others, aspects of the assessment of the contents of 77.63 with very good category, feasibility aspects of presentation 95 with very good category, aspects of learning activities green economic approached 93.75 with very good category.

The results of module validation data by media experts get a total score of 89.82 with very good category. Aspects in the value, among others, aspects of the size of the module with a score of 75 good categories, the design aspects of the module cover score obtained 91.67 categories very good, the design aspects of the contents of 89,71 modules into the category very well. Description of validation data of the module craft and entrepreneurship based on green economy by linguists get a total score of 100 with very good category.

Description of data from module validation result by practitioner got result 93,89 with very good category. The aspect is in the value that is, the content feasibility aspect of 92,50 categories is very good, the feasibility aspects of the presentation with a score of 95 categories is very good, the aspects of learning activities green economic approach with a score of 93.75 categories very good, the benefits with a score of 95.83 Category is very good.

Repairs from materials experts, media experts, linguists and learning practitioners are processed to determine the feasibility of green economy-based craft and 
entrepreneurship modules. Description of module validation data by material experts with excellent results. Description of module validation data by media experts with excellent results. Description of module validation data by linguists with excellent results and description of module validation data by learning practitioners with excellent results. The results of the assessment and feedback in the form of comments and suggestions, both of written and oral are used as consideration of product revisions. Product revisions are made to correct deficiencies and weaknesses in the craft and entrepreneurship modules to be tested. Based on all inputs and suggestions by media experts, material experts, linguists and practitioners it can be concluded that the modules craft and entrepreneurs green economy-based are feasible for production and use in improving student learning outcomes.

The result of limited test which tested to 10 students get result $67 \%$ limited trial show module is valid enough but still need improvement to the craft module and entrepreneurship. The revisions were made in accordance with the inputs and suggestions of the students on the limited test and then into the third draft which will be tested in a larger class or field trial.

Based on the result of questionnaire validation of trial 2 module obtained percentage of $81 \%$. The percentage indicates that the green economy based craft and entrepreneurship module is valid for use. The criticism and suggestions of students in general in the trial 2 as follows: 1) the writing should not be too big and many; 2) each color image is sharpened; 3) sampling is still lacking. Improvements were made to improve the overall module of craft and entrepreneurship. The module of craft and entrepreneurship after the revision becomes a draft that is ready to do test usage.

The result of posttest test in the control class has an increase from the pretreatment of 69,86 up to 70,92 and the experimental class experimental test has increased from the average value of 69,53 which experienced an increase in posttest i.e. the mean value to 83,71 . Learning outcomes show that the module craft and entrepreneurship are able to improve student learning outcomes on the subject of craft and entrepreneurship. This is evidenced by the increase in student learning outcomes in the experimental class higher than the control class.

\section{CONCLUSION AND SUGGESTION}

\section{Conclusion}

Module product required by entrepreneurship subject in SMK that is module that can overcome the limitation of time, space, interesting, improve student ability, and can improve student independence in learning. The quality of the module in terms of content feasibility aspects, language and image aspects get positive and feasible responses with good category. The result of validation of craft module and entrepreneurship based on green economy according to material experts, media experts, linguists and teachers as practitioners as users shows that the module based on the craft and entrepreneurship based on green economy is suitable to be used as a media of learning of craft and entrepreneurship. The usage test results in the experimental class showed an increase in learning outcome of 83.71 which was initially 69.53 and the control class increased by 70.92 which was originally 69.86 . The application of green 
economy-based modules has proven to improve learning outcomes in construction and entrepreneurship subjects.

\section{Suggestion}

This generated module can be utilized as one of the supporting materials that already exist. The results of this development is expected to be used as one of the variations of materials and learning media of students of class XI SMK to improve students' understanding of the subject matter of processing craft and entrepreneurship.

\section{REFERENCES}

[1] Anggraini A., Sukardi. (2015). Pengembangan Modul Prakarya Dan KewirausahaanMateri Pengolahan Berbasis Product Oriented Bagi Peserta Didik Smk. Jurnal Pendidikan Vokasi. 5 (3): 110.

[2] Sudarwati, N. (2013). Developing an Integrated Module on Entrepreneurship to Improve Ability in Making Business Plans. International Journal of Business, Humanities and Technology, 3 (5): 1-27.

[3] Matanluk, O., Mohammad, B., Kiflee N \& Imbug, M. (2013). TheEffectiveness of Using Teaching Module Based on Radical Constructivism toward Students Learning Process. International Conference on University Learning and Teaching. 607-615.

[4] [UNEP] United Nations Environment Programme. (2011). Towards a Green Economy: Pathways to Sustainable Development and Poverty Eradication.

[5] Syah, M. (2008). Psikologi Belajar. Bandung. Remaja Rosdakarya.

[6] Heinich, R., Molenda, C., Russell, J, D., \& Smaldino, S, E. (2002). Intstructional Media and Technologies for Learning: Seventh Edition. Pearson Education: New Jersey.

[7] Hamalik, Agus. (2003). Proses belajar mengajar. Jakarta: Bumi aksara.

[8] Schunk, Dale H. (2012). Learning Theories: An Educational Perspective 6th Edition. Boston: Pearson Education, Inc.

[9] Nokelainen, P. (2006). An empirical assessment of pedagogical usability criteria for digital learning material with elementary school students. Educational Technology \& Society, 9 (2): 178-197.

[10] University of Wollongong NSW 2522. (1992). Competency Based Training. Australia: National Center for Vocational Education Research Ltd/National Center for Competency Based Training.

[11] Bundsgaard, J. \& Hansen, T.I. (2011), Evaluation of Learning Materials: A Holistic Framework. Journal of Learning Desig, 4 (4): 31-46.

[12] Belawati, T., (2003). Pengembangan Bahan Ajar. Jakarta: Pusat Penerbitan UT.

[13] Hashemi, S.Z. \& Borheni, a. (2012). Textbook Evaluation: An Investigation into Touchstone Saries. Theory and Practice in Language Studies, 2 (12): 1662-2655.

[14] Hackbartt, S. (1996). The Education Technology Handbook: A Comprehensive Guide: process and Products for Learning. Englewood Cliffs, N.J.: Publications Inc

[15] Depdiknas. (2008). Panduan Pengembangan Bahan Ajar. Jakarta: Direktorat Jendral Pendidikan Dasardan Menengah.

[16] Winkel. (2009). Psikologi Pengajaran. Yogyakarta : Media Abadi.

[17] Cruces, S. (1993). Modular Instruction in the Technical Education. Paper presented at the seminar among the faculty of Western Visayas College of Science and Technology.

[18] Dewitt, D., Siraj, S., \& Alias. (2014). Collaborative mLearning: A Module for Learning Secondary School Science. Educational Technology \& Society, 17 (1), 89-101.

[19] Perinpasingam, P., Arumugam, N., \& Subramaniam, S., at all. (2014). Development of a Science Module through Interactive Whiteboard. Published by Canadian Centerof Science and Education. Vol. 6, No. 3: 31-38.

[20] Djajadaningrat, Hendriani \& Famiola. (2014). Green Economy. Bandung. Rekayasa Sains.

[21] World Bank. (2012). Inclusive Green Growth: The Pathway to Sustainable Development. Washington D.C.: The World Bank.

[22] OECD. (2011). Towards Green Growth. Paris: Organisation for Economic Co-operation and Development. 
[23] Sari, A.M. Wijaya, A.F \& Wachid, A. (2015). Penerapan Konsep Green Economy Dalam Pengembangan Desa Wisata Sebagai Upaya Mewujudkan Pembangunan Berwawasan Lingkungan. Jurnal Administrasi Publik (JAP). 2 (4): 765-770.

[24] Alma, Buchari. (2011). Kewirausahaan Untuk Mahasiswa dan Umum. Bandung: CV Alfabeta.

[25] Kettunen, J., Mertanen, L. K., \& Penttila, T. (2013).Innovation Pedagogy and Desired Learning Outcomes in Higher Education. On the Horizon, 21 (4): 333-342.

[26] Asgari, M.\& Borzooei, M., (2013). Evaluating the Learning Outcomes of International Students as Educational Tourists. Journal of Business Studies Quarterly. 5 (2): 130-140.

[27] Maher, A. (2013). Learning Outcome in Higher Education: Implications for Curriculum Design and Student Learning. Journal of Hospitality, Leisure Sport and Tourism Education, 3 (2): 46-54.

[28] Gall, M.D., Gall, J.P., \& Borg, W.R. (2003). Education research7th edition. San Fransisco: Library of Congress Cataloging inPublication Data. 